\title{
STUDI EKSPERIMENTAL DAN MODEL MATEMATIKA PENGERINGAN DAUN KELOR (MORINGA OLEIFERA) DENGAN EMPAT TIPE PENGERINGAN
}

\section{EXPERIMENTAL STUDY AND MATHEMATICAL MODEL OF MORINGA OLEIFERA LEAVES DRYING WITH FOUR DRYING TYPES}

\author{
Andi Taufan*, Mirwan Ardiansyah Karim, Novrinaldi, Satya Andika Putra, Aidil \\ Haryanto, Eko Kuncoro Pramono, dan Umi Hanifah \\ Pusat Penelitian Teknologi Tepat Guna, Lembaga Ilmu Pengetahuan Indonesia \\ Jalan K.S. Tubun No 05 Subang, (0260) 411478 \\ *E-mail: andi022@lipi.go.id
}

\begin{abstract}
ABSTRAK
Proses pengeringan daun kelor (Moringa Oleifera) diperlukan untuk mengurangi kandungan air sehingga dapat mencegah kerusakan dan memperpanjang umur simpan daun kelor. Pada penelitian ini telah dilakukan pengeringan daun kelor menggunakan pengeringan matahari dan pengering tipe rak. Pengeringan matahari dilakukan menggunakan pengeringan surya dan pengering efek rumah kaca, sedangkan pengering tipe rak menggunakan pemanas gas dan pemanas listrik. Tujuan dari penelitian ini adalah untuk melakukan perbandingan dari beberapa tipe pengeringan tersebut dan untuk mengetahui model matematis yang paling tepat untuk menggambarkan kinetika pengeringannya. Model matematis yang digunakan adalah model Newton (Lewis), Handerson dan Pabis, Page, dan Logaritmic. Pemodelan dilakukan dengan menggunakan perangkat SOLVER di Microsoft Excel berdasarkan metode iterasi General Reduced Gradient (GRG). Analisis statistik untuk mengevaluasi kesesuaian data eksperimen dengan model pengeringan menggunakan koefisien determinasi $\left(R^{2}\right)$, root mean square error (RMSE), dan reduced Chi-square $\left(\chi^{2}\right)$. Hasil eksperimen menunjukkan waktu yang dibutuhkan untuk mengeringkan daun kelor dengan menggunakan alat pengering lebih singkat dibandingkan dengan pengeringan matahari. Waktu pengeringan paling cepat diperoleh menggunakan pengering tipe rak menggunakan pemanas listrik yang mengeringkan daun kelor dari kadar air awal 80,22\% menjadi 9,52\% selama 2 jam. Sedangkan hasil analisis statistik menunjukkan model Page paling sesuai untuk menggambarkan kinetika pengeringan dibandingkan dengan model Newton (Lewis), Henderson dan Pabis, dan Logaritmic.
\end{abstract}

Kata kunci: kelor, kinetika pengeringan, model matematika, pengeringan

\section{ABSTRACT}

The drying process of Moringa Oleifera leaves is needed to reduce the water content so that it can prevent damage and extend the shelf life of Moringa leaves. In this research, Moringa leaves were dried using sun drying and rack type dryer. Open sun drying and greenhouse effect dryers were used for solar drying, while rack-type dryers used gas heating and electric heating. The purposes of this research are to compare several types of drying and to find out the most appropriate mathematical model to describe the drying kinetics of Moringa leaves. The mathematical models that are used in this research are Newton (Lewis), Handerson Pabis, Page, and Logaritmic models. The SOLVER tool in Microsoft Excel based on the General Reduced Gradient (GRG) iteration method is used for modelling. Statistical analysis to evaluate the suitability of experimental data with the drying model used the coefficient of determination (R2), root mean square error (RMSE), and reduced Chi-square ( $\chi 2)$. The experimental results showed that the time needed to dry Moringa leaves using a dryer was shorter than sun drying. The fastest drying time was obtained using a rack type dryer with an electric heater, which dried Moringa leaves from an initial moisture content of $80.22 \%$ to $9.52 \%$ for 2 hours. 
Meanwhile, statistical analysis results show that the Page model is most suitable for describing the drying kinetics compared to the Newton (Lewis), Henderson and Pabis, and Logarithmic models.

Keywords: drying, drying kinetics, mathematical model, Moringa Oleifera

\section{PENDAHULUAN}

Celor atau Moringa oleifera merupakan tanaman yang banyak ditemukan di daerah tropis maupun subtropis. Tanaman ini biasanya tumbuh liar dan dapat tumbuh dikonsumsi manusia (Manuwa et al., 2020). Daun kelor mengandung protein, lemak, karbohidrat, mineral, vitamin dan asam amino. Selain itu daun kelor juga mengandung zat aktif yang berpotensi sebagai antioksidan yaitu berbagai jenis vitamin $(A, C, E, K, B 1, B 2, B 3$, B6), flavonoid, alkaloid, saponin, tanin, dan terpenoid (Hanarisetya, 2019) sehingga dapat dimanfaatkan sebagai sumber makan untuk mengatasi masalah kekurangan gizi pada balita, ibu hamil, dan menyusui serta dapat dimanfaatkan untuk minuman dan obat. Menurut Ebere dan Emelike (2016), Moringa oleifera adalah salah satu tanaman yang menjanjikan yang dapat berkontribusi pada peningkatan asupan beberapa nutrisi penting dan phytochemical yang meningkatkan kesehatan.

Beberapa tahapan proses penanganan daun kelor diperlukan untuk memperoleh manfaatnya diantaranya adalah pengeringan, perebusan, ekstraksi dan lainnya. Pengeringan pada daun kelor diperlukan untuk mencegah kerusakan dan memperpanjang umur simpan dengan cara mengurangi kandungan air pada daun kelor. Akan tetapi pengeringan mempunyai dampak pada sifat bahan diantaranya adalah perubahan warna, hilangnya aroma, perubahan tekstur, nilai nutrisi, dan perubahan penampilan serta bentuk fisik (Ali et al., 2014). Menurut Hanarisetya (2019), proses pengeringan berpengaruh terhadap kandungan senyawa kimia yang terkandung dalam suatu tanaman terutama senyawa yang berkhasiat sebagai antioksidan. Untuk itu diperlukan penanganan pasca panen pengeringan yang sesuai dengan jenis bahan yang dikeringkan. Beberapa metode pengeringan yang dapat dilakukan untuk mengeringkan daun kelor diantaranya adalah menggunakan pengeringan surya, pengeringan efek rumah kaca (ERK), pengeringan rak dengan pemanas gas, dan pengeringan rak dengan pemanas listrik.

Pengeringan surya merupakan metode pengeringan yang paling umum digunakan oleh masyarakat. Penggunaan matahari langsung cocok diaplikasikan untuk semua jenis pengeringan dengan temperatur relatif rendah, seperti pengeringan hasil pertanian (Timoumi et al., 2004). Meskipun mendapatkan sumber energinya secara alami tanpa aliran listrik, namun metode ini sangat tergantung oleh kondisi alam seperti iradiasi, kecepatan angin, dan cuaca. Pengeringan dengan matahari telah banyak dibahas dengan berbagai macam metode seperti tipe ruang pengering, pengering matahari hibrid, pergerakan udara seperti yang terdapat di dalam penelitian dan review Nabnean et al. (2016), Lamidi et al. (2018), dan Singh et al. (2017). Begitupun dengan pengering termal dengan memanfaatkan panas juga telah banyak dibahas dan memiliki berbagai jenis model (Onwude et al., 2016).

Penelitian tentang pengeringan daun kelor telah dilakukan oleh beberapa peneliti diantaranya adalah Mbah et al. (2012) yang telah meneliti pengaruh beberapa teknik pengeringan terhadap komposisi nutrisi pada daun kelor. Ali et al. (2014) melakukan penelitian tentang pengeringan daun kelor untuk mengetahui karakteristik pengeringan dan analisa warna daun kelor dengan variasi temperatur pengeringan 40,50 dan $60{ }^{\circ} \mathrm{C}$ menggunakan oven. Potisate dan Phoungchandang (2015) melakukan eksperimen pengeringan daun kelor menggunakan microwave dan menunjukkan peningkatan signifikan senyawa fitokimia daun kelor dengan pengaplikasian pengeringan microwave. Martínez et al. (2017) melakukan pengeringan daun kelor dengan pengering sistem konveksi, vakum, dan freeze-drying untuk meninjau pengaruhnya terhadap vitamin C dan antioksidan setelah 
dikeringkan pada temperatur dan tekanan berbeda. Kinetika pengeringan biji dan daun kelor dilakukan masing-masing oleh Aremu dan Akintola (2016) dan Ali et al. (2014) menggunakan sistem kabinet tray dan oven. Menurut Premi et al. (2010), menganalisis kinetika daun kelor selama pengeringan konvektif untuk kisaran temperatur 50 hingga $80{ }^{\circ} \mathrm{C}$ dengan kecepatan udara konstan $0,5 \mathrm{~m} / \mathrm{s}$ menghasilkan sampel yang dikeringkan pada temperatur $60{ }^{\circ} \mathrm{C}$ ditemukan lebih baik warnanya dibandingkan dengan sampel yang diperoleh pada temperatur 50,70 dan $80^{\circ} \mathrm{C}$.

Penelitian ini bertujuan untuk melakukan perbandingan pengeringan menggunakan pengeringan matahari (pengeringan surya dan pengering efek rumah kaca) dan pengering rak (pengering rak dengan pemanas gas dan pengering rak dengan pemanas listrik). Selain itu penelitian dilakukan untuk mengetahui model matematis yang paling tepat untuk menggambarkan kinetika pengeringan daun kelor pada berbagai metode pengeringan.

\section{METODE PENELITIAN}

\section{Bahan}

Daun kelor segar diperoleh dari kebun di daerah kabupaten Subang. Pengujian kadar air awal dilakukan dengan metode gravimetri menggunakan alat halogen moisture analyzer, Metler Toledo tipe HB43-S. Hasil pengujian awal kadar air daun kelor segar rata-rata sebesar $80,22 \% \pm 1,9957$. Instrumen pengujian dan pengukuran untuk mengetahui kondisi bahan, alat pengeringan, dan lingkungan dapat dilihat pada Tabel 1.

Tabel 1. Instrumen pengujian dan pengukuran

\begin{tabular}{llccc}
\hline \multicolumn{1}{c}{ Instrumen } & \multicolumn{1}{c}{$\begin{array}{c}\text { Paramater } \\
\text { yang diukur }\end{array}$} & $\begin{array}{c}\text { Rentang } \\
\text { pengukuran }\end{array}$ & Resolusi & $\begin{array}{c}\text { Akurasi dan } \\
\text { Toleransi }\end{array}$ \\
\hline $\begin{array}{l}\text { HB43-S Halogen } \\
\text { moisture analyzer }\end{array}$ & Kadar air & & $0,01 \%$ & $0,015 \%-0,1 \%$ \\
\hline DFRobot DHT22 & $\begin{array}{l}\text { Temperatur } \\
\text { kelembaban } \\
\text { relatif }\end{array}$ & $\begin{array}{c}-40-80^{\circ} \mathrm{C} \\
0-100 \% \mathrm{RH}\end{array}$ & $\begin{array}{c}0,1 \%{ }^{\circ} \mathrm{C} \\
0,1 \% \mathrm{RH}\end{array}$ & $\begin{array}{c} \pm 0,5^{\circ} \mathrm{C} \\
\pm 2 \% \mathrm{RH}\end{array}$ \\
\hline Load cell & Berat & $2 \mathrm{~kg}$ & $0,001 \mathrm{~kg}$ & $\pm 0,01 \mathrm{~kg}$ \\
\hline $\begin{array}{l}\text { Solar Power Meter } \\
\text { TES 132 }\end{array}$ & Iradiasi matahari & $2000 \mathrm{~W} / \mathrm{m}^{2}$ & $1 \mathrm{~W} / \mathrm{m}^{2}$ & $\pm 5 \%$ \\
\hline
\end{tabular}

\section{Alat pengeringan}

Pengujian pengeringan daun kelor menggunakan empat metode dengan empat tipe pengeringan yaitu pengeringan surya, pengering efek rumah kaca (ERK), pengering rak dengan pemanas gas, pengering rak dengan pemanas listrik. Selama proses pengeringan dilakukan pengukuran iradiasi matahari, temperatur, $\mathrm{RH}$, dan berat daun kelor setiap 60 detik.

\section{Pengeringan surya}

Daun kelor dengan berat 100 gram diletakkan pada tampah dengan diameter $55 \mathrm{~cm}$ dan diratakan secara tipis. Jumlah tampah yang digunakan pada proses pengeringan sebanyak 10 tampah. Daun kelor pada tampah dihamparkan dibawah sinar matahari secara langsung pada koordinat $6^{\circ} 33^{\prime} 15,8^{\prime \prime} \mathrm{S} 107^{\circ} 45^{\prime} 41,1^{\prime \prime} \mathrm{E}$. 


\section{Pengering efek rumah kaca (ERK)}

Gambar 1 merupakan pengering ERK yang digunakan dalam penelitian ini berukuran 4,2 m (p) x 2,8 m (I) x 3,1 m (t). Dinding menggunakan bahan plastik UV dengan ketebalan $0,17 \mathrm{~mm}$ dan kadar UV protector 14\%. Ruang pengering dilengkapi dengan rak untuk menempatkan tampah yang berisikan daun kelor $100 \mathrm{~g} /$ tampah sebanyak 10 tampah. Turbine ventilator terpasang pada atap ruang pengering yang berfungsi sebagai ventilasi udara/sirkulasi udara untuk mengurangi kelembaban ruangan. Selain itu ERK juga dilengkapi dengan ventilasi pada bagian dinding atas sebelah utara dan selatan.

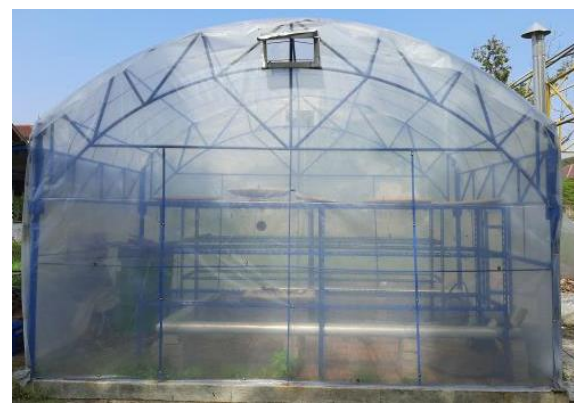

a.

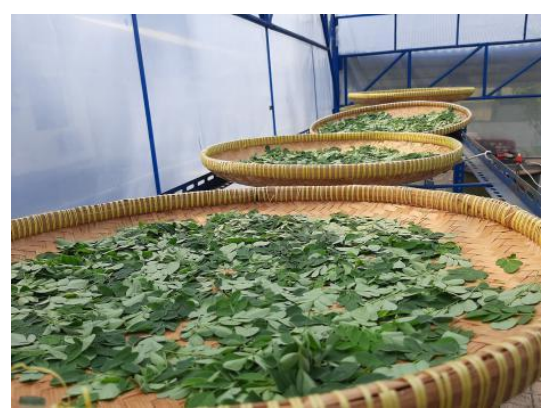

b.

Gambar 1. a) Pengering ERK. b) Penempatan tampah daun kelor dalam ruang pengering ERK.

\section{Pengering rak dengan pemanas gas}

Pengering mempunyai dimensi $2 \times 2 \times 2$ m seperti pada Gambar 2. Bagian dinding terbuat dari styrofoam tebal $40 \mathrm{~mm}$ yang dilapisi plat stainless steel 304 tebal $1 \mathrm{~mm}$ pada bagian dalam, sedangkan dinding bagian luar menggunakan plat aluminium kulit jeruk tebal $0,8 \mathrm{~mm}$. Bagian lantai menggunakan T-block tebal $20 \mathrm{~mm}$ dan menggunakan lapisan yang sama seperti dinding. Pengering ini dilengkapi 2 buah kipas di bagian depan dan belakang berukuran 12 inch, 1 buah exhaust fan berukuran 12 inch, 2 buah lubang sirkulasi udara masuk pada bagian pintu, 2 buah rak, dan 1 panel kontrol. Sebagai pemanas menggunakan Gasolec tipe S8 dengan bahan bakar LPG.

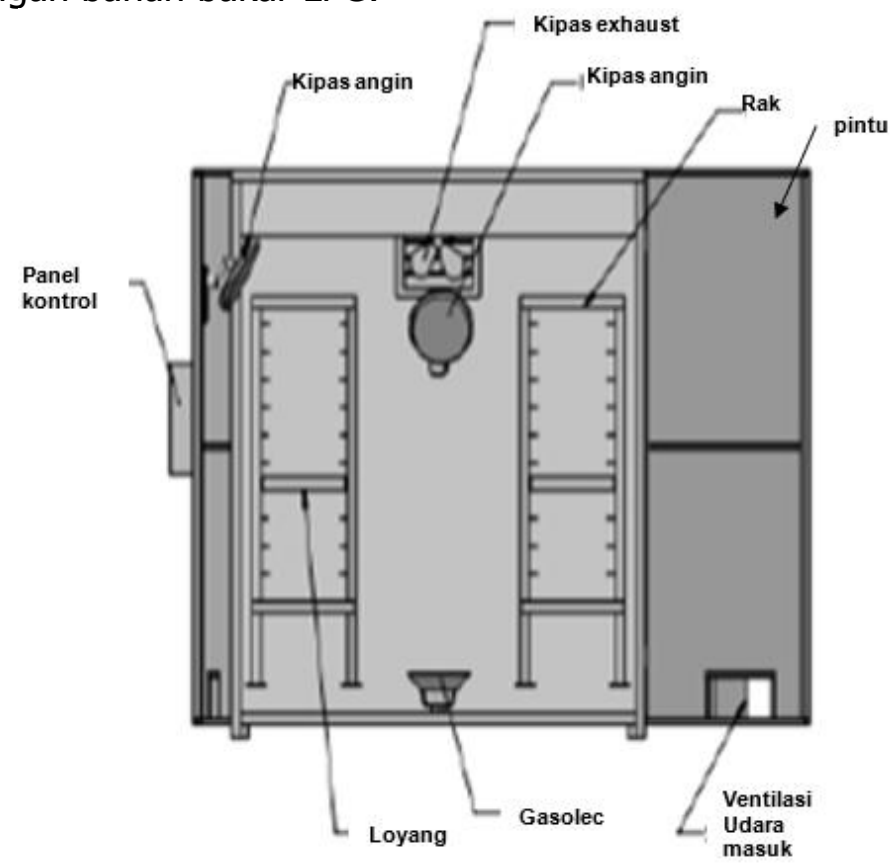

Gambar 2. Pengering rak dengan pemanas gas (Afifah, Rahayuningtyas dan Kuala, 2017).

344 Andi Taufan, Mirwan Ardiansyah Karim, Novrinaldi, Satya Andika Putra, 
Mekanisme pengeringan dilakukan dengan menyalakan burner (Gasolec) berbahan bakar LPG. Gasolec memiliki kawat frame berbahan logam khusus yang berubah warna menjadi merah saat dinyalakan. Pada saat itu kawat frame akan memancarkan panas dan gelombang infrared. Lapisan dalam dinding ruang pengering berupa plat stainlesss steel akan membantu memantulkan infra merah sehingga gelombang infra merah yang berada dalam ruang pengering dapat semaksimal mungkin dimanfaatkan untuk proses pengeringan bahan (Afifah, Rahayuningtyas dan Kuala, 2017). Ruang pengering dilengkapi dengan rak untuk menempatkan loyang yang berisikan daun kelor $100 \mathrm{gram} /$ loyang sebanyak 10 loyang.

\section{Pengering rak dengan pemanas listrik}

Pengering ini menggunakan pengering komersial keluaran Jenn Chiang Machinery works co. Itd. Pemanasan diperoleh dari pemanas listrik kemudian udara panas dialirkan melalui sistem saluran udara menuju setiap rak bahan oleh blower. Daya pemanas listrik 6000 Watt, daya motor blower $3 \mathrm{Hp}$ (2,262 Watt). Ruang pengering dilengkapi dengan rak untuk menempatkan loyang yang berisikan daun kelor 100 gram/loyang sebanyak 10 loyang.

\section{Model matematika dan analisis statistik}

Moisture ratio (MR) merupakan bilangan tidak berdimensi untuk menggambarkan rasio perubahan kadar air suatu waktu terhadap kadar air awalnya. Perhitungan MR dan laju pengeringan daun kelor selama uji coba dilakukan dengan menggunakan persamaan:

$$
\begin{gathered}
M R=\frac{M-M_{e}}{M_{o}-M_{e}} \\
D R=\frac{M_{t+d t}-M_{t}}{d t}
\end{gathered}
$$

Simplifikasi persamaan (1) dapat dilakukan seperti pada persamaan (3) (Akoy, 2014).

$$
M R=\frac{M}{M_{o}}
$$

dimana $\mathrm{M}$ adalah kadar air pada setiap waktu, $\mathrm{M}_{\mathrm{o}}$ adalah kadar air awal, $\mathrm{M}_{\mathrm{e}}$ adalah kadar air kesetimbangan, dan $M_{t}$ adalah kadar air pada waktu t. Penyederhanaan persamaan (1) disebabkan oleh kadar air kesetimbangan yang relatif kecil sehingga dapat diabaikan.

Kurva MR setiap satuan waktu disesuaikan dengan model pengeringan yang umum digunakan pada produk makanan. Model kinetika tersebut adalah Newton (Lewis), Henderson dan Pabis, Page, dan Logaritmic yang masing-masing ditunjukkan secara berurutan pada persamaan (4)-(7).

$$
\begin{gathered}
M R=e x p^{-k t} \\
M R=a \exp ^{-k t} \\
M R=\exp ^{-k t^{n}} \\
M R=\exp ^{-k t^{n}}+c
\end{gathered}
$$

Pemodelan dilakukan dengan menggunakan perangkat SOLVER di Microsoft Excel berdasarkan metode iterasi General Reduced Gradient (GRG). Metode ini dilakukan untuk melakukan optimasi nonlinear dengan kode GRG2 yang dikembangkan oleh Leon Lasdon dan Alan Waren. 
Seleksi persamaan pengeringan yang paling sesuai dengan eksperimen dilakukan dengan analisis statistik. Kesesuaian data eksperimen dengan model pengeringan dievaluasi dengan menggunakan koefisien determinasi $\left(R^{2}\right)$, root mean square error (RMSE), dan reduced Chi-square $\left(\chi^{2}\right)$. Kesesuaian terbaik dilihat dari $\mathrm{R}^{2}$ tertinggi dan RMSE, dan $\chi^{2}$ terendah (Akoy, 2014; Doymaz, 2014). Parameter-parameter tersebut diperoleh dari persamaan-persamaan berikut:

$$
\begin{aligned}
R^{2} & =1-\frac{\sum_{i=1}^{n}\left(M R_{\text {exp }, i i}-M R_{\text {pre }, i}\right)^{2}}{\sum_{i=1}^{n}\left(M R_{\text {exp }, i}-M R_{\text {pre }, i}\right)^{2}} \\
R M S E & =\sqrt{\frac{1}{N} \sum_{i=1}^{N}\left(M R_{\text {exp }, i}-M R_{\text {pred }, i}\right)^{2}} \\
\chi^{2} & =\frac{\sum_{i=1}^{N}\left(M R_{\text {exp }, i}-M R_{\text {pred }, i}\right)^{2}}{N-n}
\end{aligned}
$$

dimana $\mathrm{MR}_{\text {exp }}$ dan $\mathrm{MR}_{\text {pred }}$ adalah $\mathrm{MR}$ eksperimen dan $\mathrm{MR}$ prediksi, $\mathrm{N}$ adalah jumlah pengamatan, dan $\mathrm{n}$ adalah jumlah konstanta.

\section{HASIL DAN PEMBAHASAN}

Kondisi lingkungan pada saat pengujian dapat dilihat pada Gambar 3 yang merupakan grafik iradiasi matahari dengan rata-rata iradiasi matahari adalah $403 \mathrm{~W} / \mathrm{m}^{2}$. Iradiasi matahari terus meningkat dari jam 09.00 hingga jam 12.00, hal ini seiring dengan peningkatan temperatur udara lingkungan sedangkan $\mathrm{RH}$ lingkungan cenderung turun. Dari gambar tersebut juga mengindikasikan kondisi berawan dimana iradiasi matahari menunjukan perubahan yang fluktuatif.

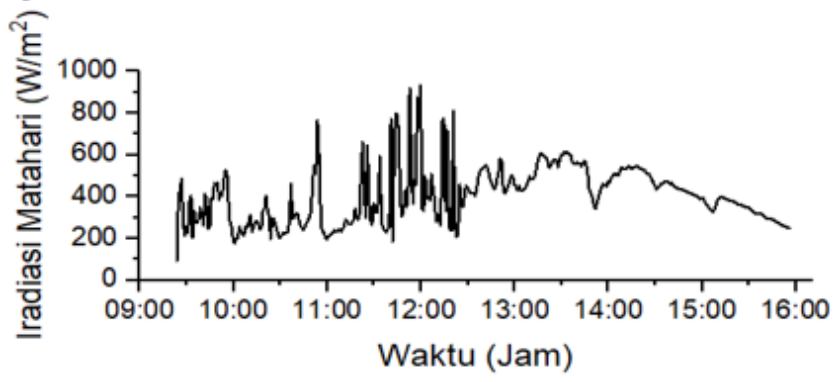

Gambar 3. Iradiasi matahari lingkungan pada pengeringan surya

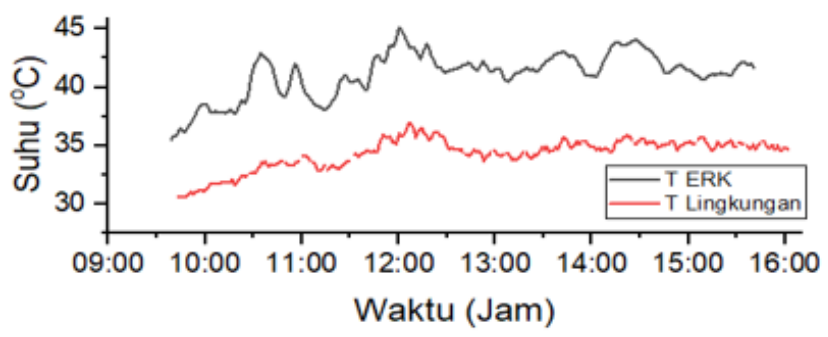

Gambar 4. Perbandingan temperatur antara pengering ERK dengan lingkungan

Rata-rata temperatur lingkungan sebesar $34,3{ }^{\circ} \mathrm{C}$, pada saat yang sama, rata-rata temperatur pada saat pengujian di pengering ERK $41,1{ }^{\circ} \mathrm{C}$ seperti pada Gambar 4 . Gambar 5 menunjukkan perbandingan $\mathrm{RH}$ antara pengering ERK dengan lingkungan dengan rata-rata masing-masing 68,2\% dan 46,2\%. Temperatur di dalam ERK lebih tinggi karena adanya efek rumah kaca. Energi surya berupa gelombang pendek yang ditransmisikan lewat atap dan 
dinding diserap oleh lantai dan benda benda lain di dalam ruang tersebut dan sebagian dipantulkan. Pantulan dalam bentuk gelombang panjang akan terperangkap di dalam ruangan sehingga terjadi akumulasi panas yang menyebabkan peningkatan temperatur di dalam ruang pengering ERK (Duffie et al., 1980; Tyagi et al., 2012).

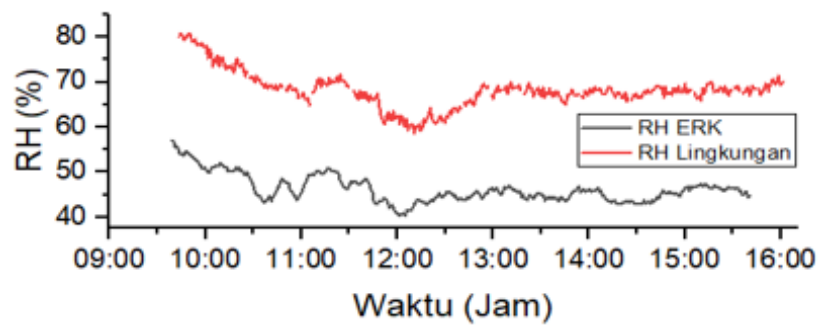

Gambar 5. Perbandingan RH antara pengering ERK dengan lingkungan

Tren kenaikan temperatur di dalam ruang pengering proporsional terhadap kenaikan iradiasi matahari. Iradiasi matahari cenderung mengalami penurunan setelah jam 12.00, namun temperatur di dalam ERK masih bertahan di kisaran $41{ }^{\circ} \mathrm{C}$. Hal ini disebabkan oleh konduktivitas termal selubung ERK yang rendah sehingga temperatur panas terperangkap lebih lama di dalam ruangan pengering.

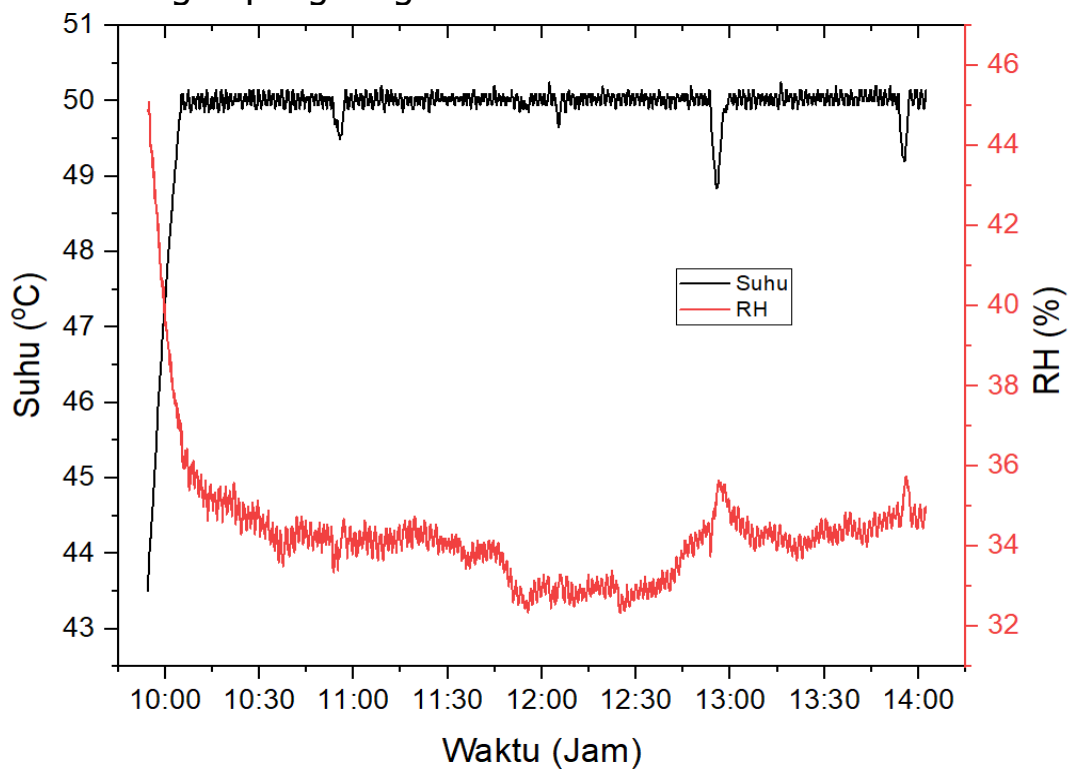

Gambar 6. Rataan temperatur dan RH di dalam ruang pengering rak dengan pemanas gas

Gambar 6 menunjukkan temperatur dan RH di dalam ruang pengering rak dengan pemanas gas. Temperatur tercatat tetap bertahan di kisaran temperatur pengaturan kecuali di beberapa saat ketika kabinet dibuka untuk keperluan penimbangan bahan. Hal ini menyebabkan temperatur tercatat mengalami penurunan akibat terpengaruh dengan temperatur lingkungan.

Penurunan RH proporsional terhadap kenaikan temperatur dimana tren $\mathrm{RH}$ terendah terjadi akibat kondisi di dalam kabinet semakin kering. Kenaikan RH yang kembali terjadi proporsional dengan turunnya temperatur pada jam 13.00. Hal ini mengindikasikan pintu kabinet terbuka cukup lama saat proses penimbangan dibandingkan dengan waktu lainnya.

\section{Kurva pengeringan}

Moisture ratio mengalami penurunan secara kontinu seiring waktu dan tipe pengeringan mempengaruhi waktu pengeringan seperti ditunjukkan Gambar 8. Pengeringan 
surya sangat tergantung dengan kondisi lingkungan seperti iradiasi matahari, temperatur, $\mathrm{RH}$, maupun kecepatan angin saat pengeringan. Oleh karena itu, pengeringan surya membutuhkan waktu 6 jam untuk mengeringkan daun kelor dari kadar air awal 80,22\% menjadi 7,99\%. Dengan kondisi cuaca yang sama, pengering ERK dapat mengeringkan daun kelor hingga $6 \%$ dalam 5 jam.

Pengeringan rak dengan pemanas listrik dapat mengeringkan daun kelor hingga di bawah standar kadar air hanya dalam 2 jam. Pengeringan dari 80,22\% hingga 9,52\% oleh pengeringan rak dengan pemanas listrik merupakan yang tercepat dibandingkan dengan tipe lainnya. Hal ini disebabkan oleh aliran udara panas yang terdistribusi dengan baik dengan kecepatan konstan dan digerakkan secara mekanis oleh blower melalui sistem saluran udara ke setiap rak. Dengan pengaturan temperatur yang sama, waktu pengeringan pada rak dengan pemanas gas lebih lambat mengeringkan bahan, yaitu dari kadar air awal hingga mencapai $6,6 \%$ dalam 3 jam. Hal ini disebabkan oleh distribusi temperatur dan kecepatan aliran udara yang tidak lebih baik.

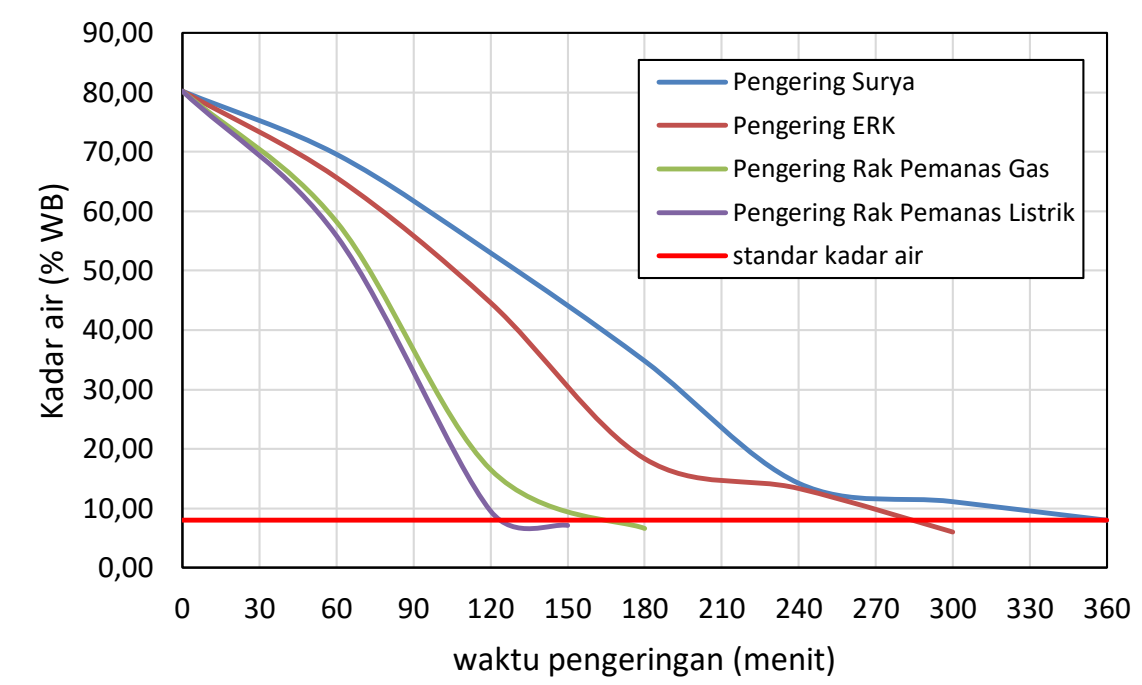

Gambar 7. Perubahan kadar air sepanjang pengeringan

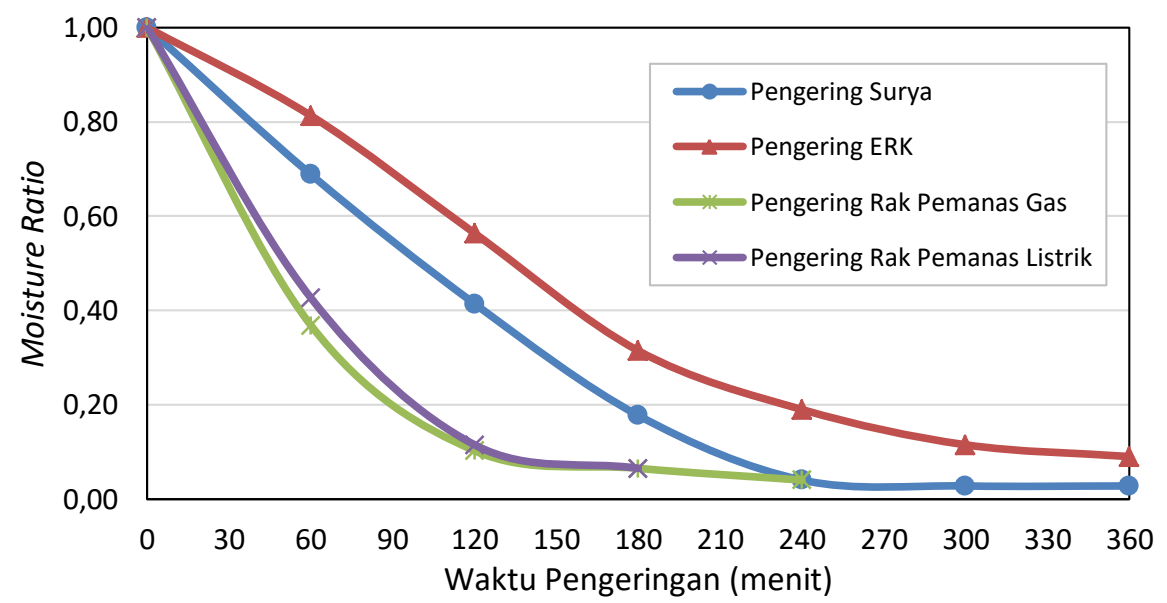

Gambar 7.Kecepatan penurunan kadar air dari empat jenis pengeringan

Gambar 8 menunjukkan laju pengeringannya. Pola dari grafik-grafik tersebut menunjukkan periode falling-rate. Laju pengeringan menurun (falling-rate) berlaku secara umum pada produk pertanian, dimana proses pengeringan pada periode ini terdiri dari dua proses yaitu perpindahan air terikat dari dalam bahan ke permukaan dan perpindahan air 
dari permukaan ke udara (Henderson dan Perry, 1955). Pada periode falling-rate ini, proses lebih dominan dipengaruhi perpindahan air terikat (bound water) melewati permukaan bahan yang memiliki laju lebih lambat dibandingkan laju penguapan air dipermukaan, seperti yang dijelaskan pada penelitian Doymaz (2014).

Target kadar air daun kelor kering dianalogikan dengan standar kadar air pada produk Teh kering dalam kemasan (SNI 3836:2013) yaitu sebesar 8\%.

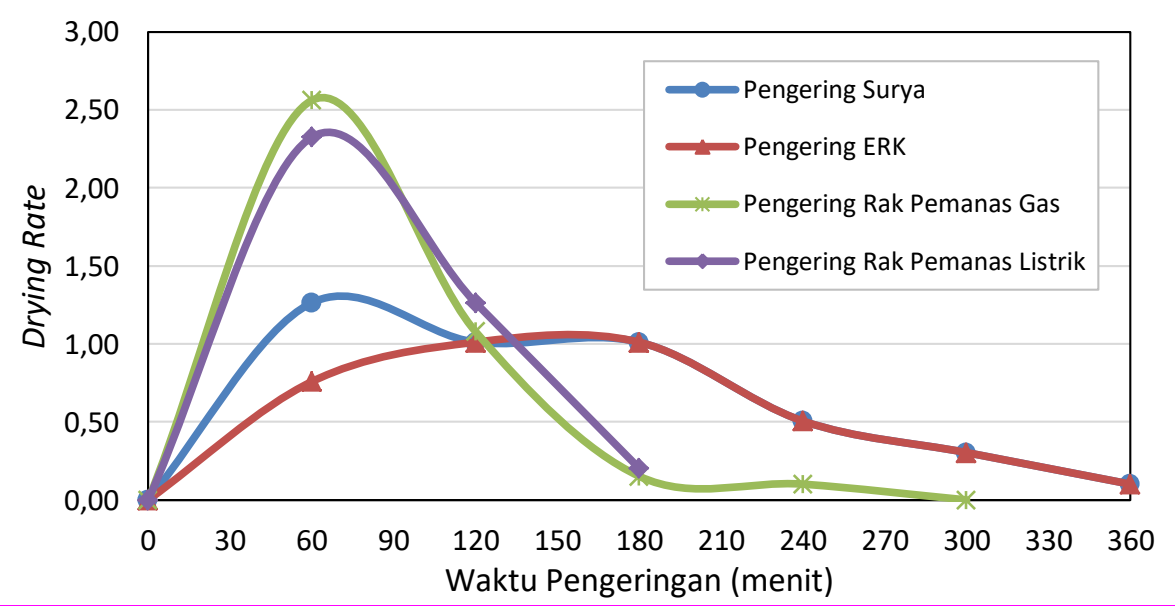

Gambar 8. Laju pengeringan

\section{Kinetika pengeringan}

Regresi non linear digunakan untuk mendapatkan nilai-nilai koefisien dan konstanta dari model persamaan (4)-(7). Hasil yang diperoleh dapat dilihat pada Tabel 2. Data kadar air eksperimen yang telah dikonversi ke MR (Gambar 10) kemudian disesuaikan dengan semua model pada tabel tersebut. Tabel 2 juga menunjukkan hasil analisis statistik setiap model dimana nilai $R^{2}$, RMSE, dan $\chi^{2}$ secara berurutan berada pada rentang $0,9809-1,000$, 0,0159-0,1753, dan 0,0005-0,0430.

Tabel 2. Hasil analisis statistik setiap model

\begin{tabular}{|c|c|c|c|c|c|c|c|c|}
\hline \multirow{2}{*}{$\begin{array}{c}\text { Model } \\
\text { Kinetika }\end{array}$} & \multirow{2}{*}{$\begin{array}{c}\text { Tipe } \\
\text { Pengeringan }\end{array}$} & \multicolumn{4}{|c|}{ Koefisien Pengeringan } & \multicolumn{3}{|c|}{ Analisis Statistik } \\
\hline & & $\mathbf{k}$ & $\mathbf{N}$ & $\mathbf{a}$ & c & $\mathbf{k}$ & $\mathbf{N}$ & $\chi^{2}$ \\
\hline \multirow[t]{4}{*}{ Newton/ Lewis } & $\begin{array}{l}\text { Pengeringan } \\
\text { surya }\end{array}$ & 0,0085 & & & & 0,9809 & 0,0574 & 0,0038 \\
\hline & Pengering ERK & 0,0043 & & & & 0,9848 & 0,1180 & 0,0162 \\
\hline & $\begin{array}{l}\text { Pengering rak } \\
\text { pemanas gas }\end{array}$ & 0,0180 & & & & 0,9981 & 0,0221 & 0,0006 \\
\hline & $\begin{array}{l}\text { Pengering rak } \\
\text { pemanas listrik }\end{array}$ & 0,0143 & & & & 0,9959 & 0,0329 & 0,0014 \\
\hline \multirow[t]{4}{*}{$\begin{array}{l}\text { Henderson } \\
\text { \&Pabis }\end{array}$} & $\begin{array}{l}\text { Pengeringan } \\
\text { surya }\end{array}$ & 0,0068 & & 1,1985 & & 0,9867 & 0,1487 & 0,0310 \\
\hline & Pengering ERK & 0,0043 & & 1,1533 & & 0,9848 & 0,1753 & 0,0430 \\
\hline & $\begin{array}{l}\text { Pengering rak } \\
\text { pemanas gas }\end{array}$ & 0,0180 & & 0,8090 & & 0,9981 & 0,0974 & 0,0158 \\
\hline & $\begin{array}{l}\text { Pengering rak } \\
\text { pemanas listrik }\end{array}$ & 0,0143 & & 0,9894 & & 0,9959 & 0,0325 & 0,0021 \\
\hline
\end{tabular}




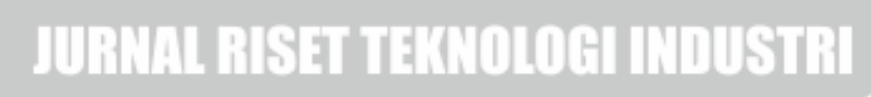

\begin{tabular}{|c|c|c|c|c|c|c|c|c|}
\hline \multirow{2}{*}{$\begin{array}{c}\text { Model } \\
\text { Kinetika }\end{array}$} & \multirow{2}{*}{$\begin{array}{c}\text { Tipe } \\
\text { Pengeringan }\end{array}$} & \multicolumn{4}{|c|}{ Koefisien Pengeringan } & \multicolumn{3}{|c|}{ Analisis Statistik } \\
\hline & & $\mathbf{k}$ & $\mathbf{N}$ & $\mathbf{a}$ & C & $\mathbf{k}$ & $\mathbf{N}$ & $\chi^{2}$ \\
\hline \multirow[t]{4}{*}{ Page } & $\begin{array}{l}\text { Pengeringan } \\
\text { surya }\end{array}$ & 0,0008 & 1,4813 & & & 0,9971 & 0,0193 & 0,0005 \\
\hline & Pengering ERK & 0,0002 & 1,6616 & & & 0,9994 & 0,0510 & 0,0036 \\
\hline & $\begin{array}{l}\text { Pengering rak } \\
\text { pemanas gas }\end{array}$ & 0,0042 & 1,3571 & & & 0,9997 & 0,0387 & 0,0025 \\
\hline & $\begin{array}{l}\text { Pengering rak } \\
\text { pemanas listrik }\end{array}$ & 0,0014 & 1,5993 & & & 1,0000 & 0,0459 & 0,0042 \\
\hline \multirow[t]{4}{*}{ Logaritmic } & $\begin{array}{l}\text { Pengeringan } \\
\text { surya }\end{array}$ & 0,0068 & & 1,1462 & $\overline{-}$ & 0,9867 & 0,0407 & 0,0029 \\
\hline & Pengering ERK & 0,0043 & & 1,2606 & $\begin{array}{c}- \\
0,2247\end{array}$ & 0,9848 & 0,0410 & 0,0029 \\
\hline & $\begin{array}{l}\text { Pengering rak } \\
\text { pemanas gas }\end{array}$ & 0,0180 & & 0,9835 & 0,0190 & 0,9981 & 0,0159 & 0,0006 \\
\hline & $\begin{array}{l}\text { Pengering rak } \\
\text { pemanas listrik }\end{array}$ & 0,0143 & & 1,0379 & $\begin{array}{c}- \\
0,0343\end{array}$ & 0,9959 & 0,0237 & 0,0023 \\
\hline
\end{tabular}

Hasil analisis statistik menunjukkan model Page paling sesuai untuk menggambarkan kinetika pengeringan untuk keempat sistem pengesringan daun kelor yang diuji. Model Page menunjukkan nilai tertinggi $\mathrm{R}^{2}$, sedangkan nilai RMSE dan $\chi^{2}$ terendah untuk semua sistem pengeringan daun kelor dibandingkan dengan model lainnya. Hal ini sejalan dengan penelitian (Aremu dan Akintola, 2016) tentang pengeringan biji kelor, penelitian Günhan et al. (2005) tentang pengeringan daun salam dan penelitian Afifah et al. (2017) tentang pengeringan beberapa jenis komoditas pertanian yang menunjukkan hasil model Page paling sesuai untuk proses pengeringan beberapsa komoditas pertanian tersebut. Jika dibandingkan dengan model Page pengeringan daun kelor menggunakan oven yang dilakukan oleh Ali et al. (2014) yang memiliki nilai $\mathrm{R}^{2}$ antara $0,998 \mathrm{~s} / \mathrm{d}$ 0,999 dan nilai $\chi^{2}$ antara $0,0002 \mathrm{~s} / \mathrm{d}$ 0,0008 , nilai $\mathrm{R}^{2}$ dan $\chi^{2}$, model Page pada penelitian ini lebih tinggi untuk pengering ERK, pengering tipe rak berbahan bakar gas, dan pengering tipe rak dengan pemanas listrik. Adapun pada pengeringan surya memiliki $\mathrm{R}^{2}$ lebih rendah (kurang dari 0,998 ) dengan $\chi^{2}$ masuk dalam rentang 0,0002 s/d 0,0008. Gambar 10 secara lebih jelas menunjukkan perbandingan data eksperimen dengan data prediksi model pada setiap sistem pengeringan. Dari gambar dapat dilihat bahwa MR eksperimen dan prediksi model Page memiliki kesesuaian yang baik (MR exp $=$ MR pre) dimana ditunjukkan dengan kedekatan hasil dengan garis lurus $45^{\circ}$.

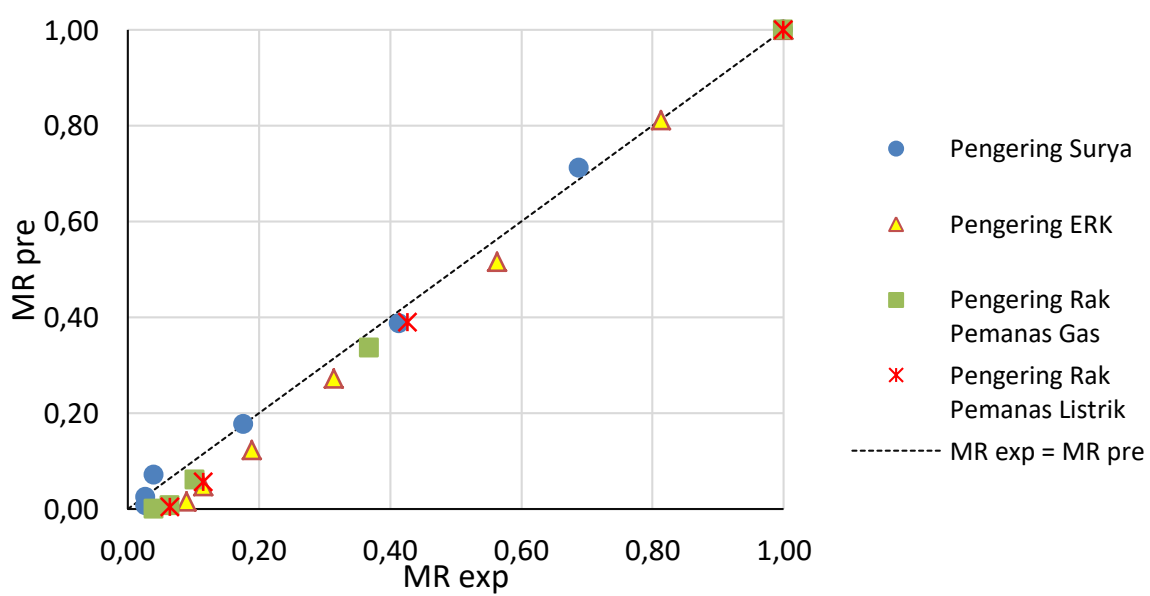

Gambar 9. Perbandingan nilai MR eksperimental dengan MR prediction dengan model Page, $R^{2}=$ 0,9952 


\section{KESIMPULAN}

Proses pengeringan menggunakan alat pengeringan memiliki waktu pengeringan yang lebih singkat dibandingkan dengan pengeringan matahari. Pengering tipe rak menggunakan pemanas listrik memiliki waktu pengeringan lebih cepat dibanding pengering tipe rak menggunakan pemanas gas. Waktu yang dibutuhkan pengering tipe rak dengan pemanas listrik untuk mengeringkan daun kelor dengan kadar air awal 80,22\% menjadi $9.52 \%$ adalah 2 jam. Model Page paling sesuai untuk menggambarkan kinetika pengeringan daun kelor di keempat jenis tipe pengeringan yang diuji dibandingkan model Newton (Lewis), Henderson dan Pabis, dan Logaritmic. Model page untuk pengeringan surya, pengering ERK, pengering rak pemanas gas, dan pengering rak pemanas listrik masing-masing secara berurutan yaitu $M R=\exp ^{-0.0008 t^{1.4813}}, \quad M R=\exp ^{-0.0002 t^{1.6616}}, M R=\exp ^{-0.0042 t^{1.3571}}$, dan $M R=$ $\exp ^{-0.0014 t^{1.5993}}$.

\section{DAFTAR PUSTAKA}

Afifah, N., Rahayuningtyas, A. and Kuala, S. I. 2017. Pemodelan Kinetika Pengeringan Beberapa Komoditas Pertanian Menggunakan Pengering Inframerah. Agritech. 37(2). pp: 220-228.

Akoy, E. 2014. Experimental characterization and modeling of thin-layer drying of mango slices. International Food Research Journal. 21. pp: 1911-1917.

Ali, A. et al. 2014. Drying Kinetics and Colour Analysis of Moringa Oleifera Leaves. in Agriculture and Agricultural Science Procedia. doi: 10.1016/j.aaspro.2014.11.055.

Aremu, A. and Akintola, A. 2016. Drying Kinetics of Moringa (Moringa oleifera) Seeds. Journal of Life Sciences and Technologies. doi: 10.18178/jolst.4.1.7-10.

Doymaz, İ. 2014. Drying Kinetics and Rehydration Characteristics of Convective Hot-Air Dried White Button Mushroom Slices. Journal of Chemistry, 2014. pp: 1-8. doi: $10.1155 / 2014 / 453175$.

Duffie, J. A., Beckman, W. A. and Blair, N. 1980. Solar engineering of thermal processes, photovoltaics and wind. New York: John Wiley \& Sons.

Ebere, C. and Emelike, N. 2016. Effect of Drying Techniques of Moringa Leaf on the Quality of Chin-Chin Enriched with Moringa Leaf Powder. 10. pp: 65-70. doi: 10.9790/24021004016570.

Günhan, T. et al. 2005. Mathematical modeling of drying bay leaves. Energy Conversion and Management. 46. pp: 1667-1679. doi: 10.1016/j.enconman.2004.10.001.

Hanarisetya, N. 2019. Pengaruh Cara Pengeringan dan Perebusan Terhadap Aktivitas Antioksidan dan Mutu Organoleptik Daun Kelor (Moringa Oleifera Lamk). Universitas Sahid Jakartya.

Henderson, S. . and Perry, R. . 1955. Agricultural process engineering. New York: John Wiley \& Sons, Inc. Available at: https://babel.hathitrust.org/cgi/pt?id=mdp.39015021218170\&view=1up\&seq=7.

Lamidi, R. et al. 2018. Recent advances in sustainable drying of agricultural produce: A review. Applied Energy. 233-234. pp: 367-385. doi: 10.1016/j.apenergy.2018.10.044.

Manuwa, S. I., Sedara, A. and Tola, F. A. 2020. Design, Fabrication and Performance Evaluation of Moringa (Oleifera) Dried Leaves Pulverizer. Journal of Agriculture and Food Research. p: 100034. doi: 10.1016/j.jafr.2020.100034.

Martínez, K., Talavera, G. and Alonso, J. 2017. Effect of Three Drying Methods on Antioxidant Efficiency and Vitamin C Content of Moringa oleifera Leaf Extract. International Journal of Chemical and Materials Engineering. 11. pp: 754-757. doi: 10.1999/1307-6892/10008255.

Mbah, B. O., Eme, P. and Paul, A. E. 2012. Effect of Drying Techniques on the Proximate and Other Nutrient Composition of Moringa oleifera Leaves from Two Areas in Eastern 
Nigeria. Pakistan Journal of Nutrition. 11. pp: 1044-1048. doi: 10.3923/pjn.2012.1044.1048.

Nabnean, S. et al. 2016. Experimental performance of a new design of solar dryer for drying osmotically dehydrated cherry tomatoes. Renewable Energy. 94. pp: 147-156. doi: 10.1016/j.renene.2016.03.013.

Onwude, D., Hashim, N. and Chen, G. 2016. Recent advances of novel thermal combined hot air drying of agricultural crops. Trends in Food Science \& Technology. 57. pp: 132145. doi: 10.1016/j.tifs.2016.09.012.

Potisate, Y. and Phoungchandang, S. 2015. Microwave drying of Moringa oleifera (Lam.) leaves: drying characteristics and quality aspects. Asia-Pacific Journal of Science and Technology. 20(1). pp: 12-25.

Premi, M. et al. 2010. Kinetics of drumstick leaves(Moringa oleifera) during convective drying. African Journal of Plant Science. 4(10). pp: 391-400.

Singh, P., Shrivastava, V. and Kumar, A. 2017. Recent developments in greenhouse solar drying: A review. Renewable and Sustainable Energy Reviews. 82. doi: 10.1016/j.rser.2017.10.020.

SNI 3836:2013. Teh Kering Dalam Kemasan. 2013.

Timoumi, S., Mihoubi, D. and Zagrouba, F. 2004. Simulation model for a solar drying process. Desalination. 168(1-3). pp: 111-115. doi: 10.1016/j.desal.2004.06.175.

Tyagi, V. . et al. 2012. Review on solar air heating system with and without thermal energy storage system. Renewable and Sustainable Energy Reviews, 16(4). pp: 2289-2303. 